\title{
TRYPSIN-MEDIATED ACTIVATION OF THE ๙-HAEMOLYSIN OF STAPHYLOCOCCUS AUREUS
}

\author{
G. M. Wiseman, J. D. Caird and H. B. Fackrell* \\ University of Manitoba Department of Medical Microbiology, Winnipeg, Canada
}

\section{Plate I}

RECENT work in this laboratory indicated that the $\alpha$-toxin of Staphylococcus aureus strain Wood 46 is produced by the organisms as an inactive proteolytic enzyme (Wiseman and Caird, 1970). Both the proteolytic and haemolytic activities of activated toxin have been shown to be neutralised by $\alpha$-antitoxin (Wiseman and Caird, 1972). It has also been suggested that this $\alpha$-" protoxin" is activated by erythrocyte proteases and that the level of protease activity in red cells of various species explains their differing sensitivity to the toxin. In our study of this phenomenon, we were interested to know whether other proteolytic enzymes could serve as activators and our attention was thus directed toward trypsin.

\section{MATERIALS AND METHODS}

Production and purification of $\alpha$-haemolysin. Crude protoxin was prepared from the Wood-46 strain of $S$. aureus by a method similar to that given by Gow and Robinson (1969) except that air rather than pure oxygen was used in conjunction with carbon dioxide to provide the gaseous environment during growth.

Gel filtration and ion-exchange chromatographic procedures were as follows. A K50 $\times 100-\mathrm{cm}$ column containing Sephadex G-75 (Pharmacia, Montreal, Canada) was set up according to the manufacturer's instructions and equilibrated with Hallander's buffer (Hallander, 1963). Haemolysin was applied to the column in 5-ml volumes and 15-ml fractions were collected by upward elution.

Ion-exchange chromatography was performed on a column of carboxymethylcellulose (CMC) according to the method of Robinson, Thatcher and Montford (1960). Haemolysin samples were dialysed against distilled water for $24 \mathrm{~h}$, centrifuged and then dialysed against $0.056 \mathrm{M}$ sodium-phosphate buffer, $p \mathrm{H} 6 \cdot 0$. Five-ml volumes of haemolysin were applied to a column equilibrated with the same buffer. The haemolysin was eluted in $15-\mathrm{ml}$ fractions from the column by the gradient described by Robinson et al. (1960).

Ammonium-sulphate fractionation of partially purified haemolysin was performed in which haemolysin was divided into eight fractions, to each of which the salt was added in concentrations between 0 and $100 \%$ saturation. The precipitates, held overnight at $4{ }^{\circ} \mathrm{C}$, were centrifuged, resuspended and dialysed against phosphate-buffered saline.

The purification procedure was the method developed in this laboratory (Fackrell, 1973). The technique of methanol precipitation of $\alpha$-haemolysin, described by Wittler and Pillemer (1948), was re-examined. Crude haemolysin adjusted to $p \mathrm{H} 4.0$ was mixed with methanol at $-20^{\circ} \mathrm{C}$ to a final concentration of $35 \%(\mathrm{v} / \mathrm{v})$ solvent and the precipitate after harvesting was dialysed against phosphate-buffered saline. As a second step, methanol-precipitated

Received 8 Jan. 1974; revised version accepted 8 Mar. 1974.

* Present address: Department of Biology, University of Windsor, Canada. 
haemolysin was purified further by precipitating with ammonium sulphate in the range of $50-60 \%$ saturation. About $70 \%$ of the haemolysin was precipitated at this concentration of the salt and this step was accompanied by a two-fold increase in specific activity.

Fractionation of the $\alpha$-haemolysin by gel filtration on Sephadex G-75 was a third step which gave a further six-fold increase in specific activity. The relative elution volume of the haemolysin was 1.45 , the haemolytic activity appearing between two major peaks of protein. A second ammonium-sulphate precipitation was performed at this stage, primarily to concentrate and stabilise the activity of material recovered from gel filtration. The precipitate obtained was prepared for chromatography on CMC. The $\alpha$-haemolysin was eluted from the CMC column with the third peak of protein, as shown earlier by Gow (1968). Most of the haemolytic activity was recovered in this step and the purified product was stored under saturated ammonium sulphate at $4^{\circ} \mathrm{C}$.

A summary of the procedure is given in table $\mathrm{I}$, which shows that a 308-fold purification of the $\alpha$-toxin was achieved and that $39 \%$ of the original activity was recovered. The specific activity of the final product is 125,000 haemolytic units (HU) per mg protein, rather higher than activities reported for earlier procedures by Arbuthnott (1970).

Purified toxin was dermonecrotic and lethal for rabbits and mice, possessed a haemolytic spectrum similar to that given by Bernheimer and Schwartz (1963) and by Wiseman and Caird (1970, 1972), and its activity was neutralised by Wellcome CPP97/63 antitoxin. Freshly prepared purified toxin had an $\mathrm{S}_{20_{\mathrm{w}}}$ value of $1.4 \mathrm{~S}$ but this increased to $3.0 \mathrm{~S}$ after standing for several days (Fackrell and Wiseman, 1975). Furthermore, the purified $\alpha$-toxin was not immunologically reactive with immunoglobulins prepared from rabbits given injections of purified $\beta-, \gamma$ - and $\delta$-haemolysins. Evidence of homogeneity of the toxin preparation used in the present study has been presented elsewhere (Fackrell and Wiseman, 1974).

Assay methods. Haemolytic activity was measured according to the method outlined by Wiseman and Caird (1972). Proteolytic activity was assayed according to the technique described by Hummel (1959) in which $p$-toluenesulphonyl-L-arginine methylester (TAME) was used as a substrate. This method, modified slightly, was performed as follows. TAME $(0.3 \mathrm{ml}$ of a solution containing $37.9 \mathrm{mg}$ in $10 \mathrm{ml}$ buffer) was placed in a spectrophotometer cuvette. The supernatant fluid $(0.5 \mathrm{ml})$ to be assayed was added and the volume brought to $2.8 \mathrm{ml}$ with $0.01 \mathrm{M}$ phosphate buffered saline, $p \mathrm{H} 7.0$. This solution was incubated at $37^{\circ} \mathrm{C}$ in the spectrophotometer for $5 \mathrm{~min}$., extinction readings at $247 \mathrm{~nm}$ being taken at 30 -s intervals. In some experiments, the time of incubation was longer. No difficulty was encountered in assays of trypsin at this $p \mathrm{H}$ in the absence of calcium ions. The method of Fraenkel-Conrat, Harris and Levy (1955) was used to prepare N-terminal amino acids from

TABLE I

Summary of data for purification of $\alpha$-haemolysin

\begin{tabular}{|c|c|c|c|c|c|}
\hline Step & $\begin{array}{c}\text { Total } \\
\text { haemolytic } \\
\text { activity } \\
(\mathrm{HU})^{*}\end{array}$ & $\begin{array}{c}\text { Recovery } \\
(\%)\end{array}$ & $\begin{array}{c}\text { Total } \\
\text { protein } \\
(\mathrm{mg})\end{array}$ & $\begin{array}{c}\text { Specific } \\
\text { activity } \\
\text { (HU per } \mathrm{mg} \text { ) }\end{array}$ & $\begin{array}{l}\text { Purification } \\
\text { factor }(\times)\end{array}$ \\
\hline $\begin{array}{l}\text { Crude haemolysin } \\
\text { Methanol precipitate }\end{array}$ & $\begin{array}{l}2.02 \times 10^{7} \\
1.13 \times 10^{7}\end{array}$ & $\begin{array}{r}100 \\
56\end{array}$ & $\begin{array}{r}49,962 \\
6304\end{array}$ & $\begin{array}{r}405 \\
1800\end{array}$ & $\begin{array}{l}1 \\
4\end{array}$ \\
\hline $\begin{array}{l}\text { Ammonium sulphate } \\
\text { precipitation } \\
\text { Sephadex G-75 }\end{array}$ & $\begin{array}{l}7 \cdot 40 \times 10^{6} \\
8 \cdot 12 \times 10^{6}\end{array}$ & $\begin{array}{l}36 \\
40\end{array}$ & $\begin{array}{r}1755 \\
335\end{array}$ & $\begin{array}{r}4200 \\
24,200\end{array}$ & $\begin{array}{l}10 \\
60\end{array}$ \\
\hline $\begin{array}{l}\text { Ammonium sulphate } \\
\text { precipitation } \\
\text { CM cellulose }\end{array}$ & $\begin{array}{l}8.20 \times 10^{5} \\
7.79 \times 10^{5}\end{array}$ & $\begin{array}{l}40 \\
41 \\
39\end{array}$ & $\begin{array}{r}505 \\
185 \\
62\end{array}$ & $\begin{array}{r}24,200 \\
44,200 \\
125,000\end{array}$ & $\begin{array}{r}00 \\
109 \\
308\end{array}$ \\
\hline
\end{tabular}

* Haemolytic units. 
ACTIVATION OF STAPHYLOCOCCAL $\alpha$-HAEMOLYSIN
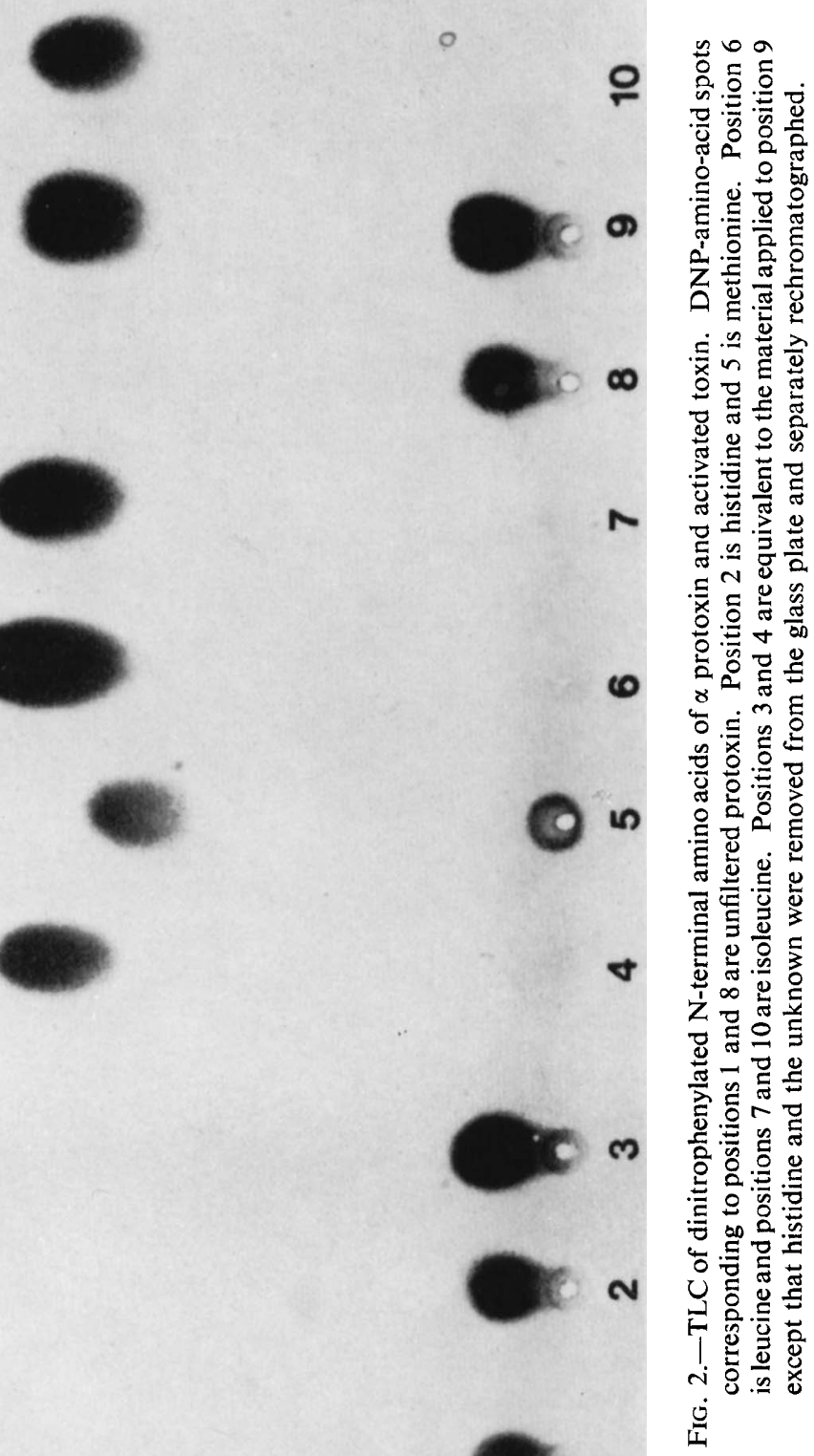
the protein. Standard dinitrophenyl (DNP) amino acids were purchased from SchwarzMann, New York. The N-terminal groups were separated and identified by thin-layer chromatography as described elsewhere in this paper.

Preparation of CMC-trypsin complex. Trypsin (Worthington, crystallised) was coupled to $\mathrm{CMC}$ in the presence of $\mathrm{N}, \mathrm{N}^{\prime}$-dicyclohexylcarbodiimide (Sigma) by the method given in Campbell et al. (1970). In the product obtained, proteolytic activity was associated with the CMC particles but was absent from the supernatant fiuid.

Spectrophotometry. A Unicam SP800B double-beam recording spectrophotometer equipped with an SP825 series-B program controller was used. In some experiments, it was advantageous to use a split spectrophotometer cuvette (Pyrocell Manufacturing, Westwood, New Jersey, USA) in which the substrate (TAME) and enzyme (trypsin or activated toxin) were placed in the compartments in tandem positions. The contents of this cuvette were then compared with those of a single-compartment cuvette which contained both enzyme and substrate mixed together. The technique resembled that used in obtaining difference spectra (Herskovits, 1967).

Thin-layer chromatography (TLC). Glass plates measuring $20 \times 20 \mathrm{~cm}$ were coated with Silica Gel G (Merck and Co., Darmstadt) to a thickness of $0.25 \mathrm{~mm}$ in a Fisher "Quick Fit " TLC apparatus equipped with automatic plate levelling. The silica gel was prepared as a slurry in water, consisting of one part gel and two parts water, before being applied to the plates. Prepared plates were dried overnight at room temperature.

Samples of DNP-amino acids were applied $1 \mathrm{~cm}$ from the edge of the plate and were developed until the solvent had travelled $10-15 \mathrm{~cm}$ upward. Plates were removed from the tanks, dried, and the positions of the spots were recorded diagrammatically or photographically.

For TLC in a single dimension, several solvent systems were used as described by Pataki (1966). These were chloroform/benzyl alcohol/acetic acid $(70: 30: 3, \mathrm{v} / \mathrm{v} / \mathrm{v})$ and benzene/ pyridine/acetic acid $(80: 20: 2, \mathrm{v} / \mathrm{v} / \mathrm{v})$. Attempts were made to separate leucine and isoleucine by two-dimensional TLC. These chromatograms were developed initially in toluene/ pyridine/2-chloroethanol/25\% $\mathrm{NH}_{4} \mathrm{OH}(50: 15: 35: 7, \mathrm{v} / \mathrm{v} / \mathrm{v} / \mathrm{v})$, and secondary development was effected at right angles to the first in chloroform/methanol/acetic acid (95: $5: 1, \mathrm{v} / \mathrm{v} / \mathrm{v})$.

TABLE II

Effect of trypsin on $\alpha$-protoxin of Staphylococcus aureus

\begin{tabular}{l|cc}
\hline Test & $\begin{array}{c}\text { Haemolytic } \\
\text { activity } \\
\text { (HU per ml) }\end{array}$ & $\begin{array}{c}\text { Proteolytic } \\
\text { activity } \\
\left(E_{247}\right)\end{array}$ \\
\hline Trypsin control* & $<10$ & 1.64 \\
Trypsin+STI $\dagger$ & $<10$ & 0.06 \\
STI control & $<10$ & 0.04 \\
Toxin control $\$$ & 747 & 0.02 \\
Toxin treated with trypsin for & 730 & 0.88 \\
30 s & 678 & 0.88 \\
1 min. & 526 & 0.57 \\
5 min. & 170 & 0.26 \\
30 min. & 53 & 0.20 \\
60 min. & 21 & 0.21 \\
\hline
\end{tabular}

* Trypsin concentration $=200 \mu \mathrm{g}$ per ml.

$\uparrow$ Soybean trypsin inhibitor. Action of trypsin was stopped by addition of $200 \mu \mathrm{g}$ per ml of this followed by immersion in ice water.

$\ddagger$ Protoxin is by definition non-haemolytic but becomes haemolytic in the presence of red cells because of their content of activating protease.

J. MED. MICROBIOL.-VOL. 8 (1975) 


\section{RESULTS}

Degradation of protoxin protein by trypsin. The action of trypsin on protoxin was investigated in the absence of CMC before activation studies were initiated. Protoxin was mixed with an equal volume of trypsin dissolved in Tris buffer at $p \mathrm{H} \mathrm{7.0.} \mathrm{This} \mathrm{mixture} \mathrm{was} \mathrm{incubated} \mathrm{at} 37^{\circ} \mathrm{C}$ in a water bath and, at various times between $30 \mathrm{~s}$ and $60 \mathrm{~min}$., soybean trypsin inhibitor was added to stop the reaction. After this the tubes were plunged into ice water. Results shown in table II indicate that protoxin is almost immediately degraded, but that the maximal rate of degradation is not reached before 5 minutes' exposure to trypsin. It will also be noted that proteolytic activity and haemolytic activity are destroyed in parallel. In subsequent experiments, protoxin was exposed to CMC-trypsin for not more than $30 \mathrm{~s}$ before centrifugation in the cold.

Activation of protoxin by trypsin. The action of CMC-trypsin complex on $\alpha$-protoxin was investigated according to the experimental design outlined in table III. Tubes containing the reagents given in this table were incubated at $37^{\circ} \mathrm{C}$ for $30 \mathrm{~s}$ with gentle shaking, after which they were immersed in ice water. Soybean trypsin inhibitor was not added. The contents were centrifuged at $2000 \mathrm{~g}$ for $15 \mathrm{~min}$. and passed through Swinney-type filters fitted with washed cellulose-acetate membranes of pore size $0.45 \mu \mathrm{m}$ (RB Filters, Toronto, Ontario). This was necessary because CMC-trypsin supernatants contained proteolytic activity associated with finely suspended CMC particles. Filtration removed this particulate material and its associated activity. Supernatant fluids were then assayed for hydrolysis of TAME.

From fig. 1 it can be seen that hydrolysis of TAME in the presence of toxin activated by CMC-trypsin complex proceeds in approximately a linear manner over a period of $13 \mathrm{~min}$. Separate controls of protoxin and supernatant fluids of $\mathrm{CMC}, \mathrm{CMC}$ and protoxin, and CMC-trypsin complex show no hydrolytic activity.

TABLE III

Reaction mixtures for experiment shown in table IV

\begin{tabular}{|c|c|c|c|c|}
\hline \multirow{2}{*}{ Additions } & \multicolumn{4}{|c|}{$\begin{array}{l}\text { Volume }(\mathrm{ml}) \text { of reagents added } \\
\text { to reaction number }\end{array}$} \\
\hline & 1 & 2 & 3 & 4 \\
\hline $\begin{array}{l}\text { Alpha protoxin* } \\
\text { CMC slurry } \dagger \\
\text { CMC-trypsin complex } \ddagger \\
\text { Buffer§ }\end{array}$ & $\begin{array}{l}2 \cdot 0 \\
0 \\
0 \\
3 \cdot 0\end{array}$ & $\begin{array}{l}2 \cdot 0 \\
2 \cdot 0 \\
0 \\
1 \cdot 0\end{array}$ & $\begin{array}{l}2 \cdot 0 \\
0 \\
2 \cdot 0 \\
1 \cdot 0\end{array}$ & $\begin{array}{l}0 \\
0 \\
2 \cdot 0 \\
3 \cdot 0\end{array}$ \\
\hline
\end{tabular}

* Haemolytic activity was $901 \mathrm{HU}$ per ml.

$\dagger$ CMC concentration was $32 \mathrm{mg}$ per $\mathrm{ml}$ dry weight.

Trypsin activity was 22 units per mg dry weight CMC.

$\S$ Buffer was $0.01 \mathrm{M}$ phosphate, $p \mathrm{H} 7 \cdot 0$, made $0.15 \mathrm{M}$ in respect of $\mathrm{NaCl}$. 


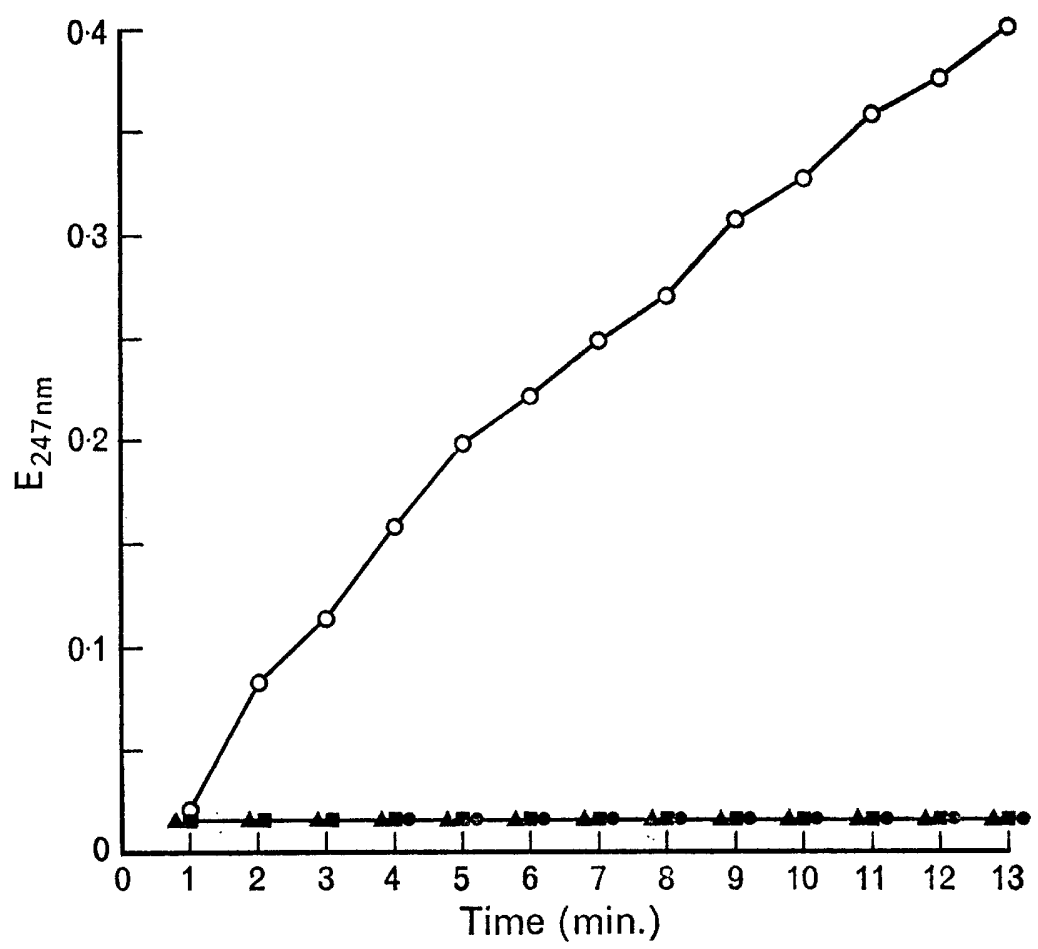

FIG. 1.-Hydrolysis of TAME by $\alpha$-toxin activated by CMC-trypsin complex: contained protoxin alone; $\Delta-\Delta$ reaction 4 , contained supernate of CMC-trypsin complex; - - reaction 2, contained supernate of a mixture of protoxin and $\mathrm{CMC} ; \mathrm{O}-\mathrm{O}$ reaction 3 contained supernate of a mixture of protoxin and CMC-trypsin complex. The composition of reaction mixtures is given in table III.

TABLE IV

Recovery of haemolytic activity after filtration of activated and unactivated $\alpha$-toxin

\begin{tabular}{c|crc}
\hline $\begin{array}{c}\text { Samples } \\
\text { reaction }\end{array}$ & $\overbrace{\text { unfiltered toxin }}^{\text {Haemolytic titres (HU per ml) of }}$ & $\begin{array}{c}\% \\
\text { filtered toxin }\end{array}$ & \\
\hline $1^{*}$ & $901 \dagger$ & 45 & 5 \\
2 & 671 & 34 & 5 \\
3 & 531 & 341 & 65 \\
4 & $<16$ & $<16$ & $\cdots$ \\
\hline
\end{tabular}

* Reaction mixtures are given in table III.

$\dagger$ Each titre is the mean of four determinations. 
Effect of filtration on protoxin and activated toxin. When small volumes of protoxin were passed through the Swinney filter only $5 \%$ of its activity was recovered as shown in table IV. It should be understood that protoxin by definition is not haemolytic, but if it is to be detected, the protoxin must be mixed with erythrocytes which contain the activating protease. In contrast to the recovery of $5 \%$ of protoxin, $65 \%$ of the trypsin-activated toxin was recovered as shown also in table IV. It should be noted that the titres of unfiltered reaction mixtures indicate that some of the haemolytic activity has been removed by CMC.

$N$-termini of filtered protoxin and activated toxin. As shown in fig. 2, single dimensional TLC of DNP-amino acids of protoxin in benzene/pyridine/ acetic acid confirmed that histidine is the $\mathrm{N}$-terminus. This determination was made by the use of unfiltered protoxin, because filtration removed much of the haemolytic activity. Chromatograms of filtered, activated toxin showed two spots one of which was histidine. The other spot migrated in the solvent close to leucine and isoleucine, the $\mathrm{Rf}$ values of which were almost equal. Methionine also moved close to the unknown, but was not identical with it (fig. 2). This was confirmed by the use of the chloroform/benzyl alcohol/acetic acid solvent system in which methionine was well separated from the unknown. The only amino acids that moved in benzene/pyridine/acetic acid with $R f$ values close

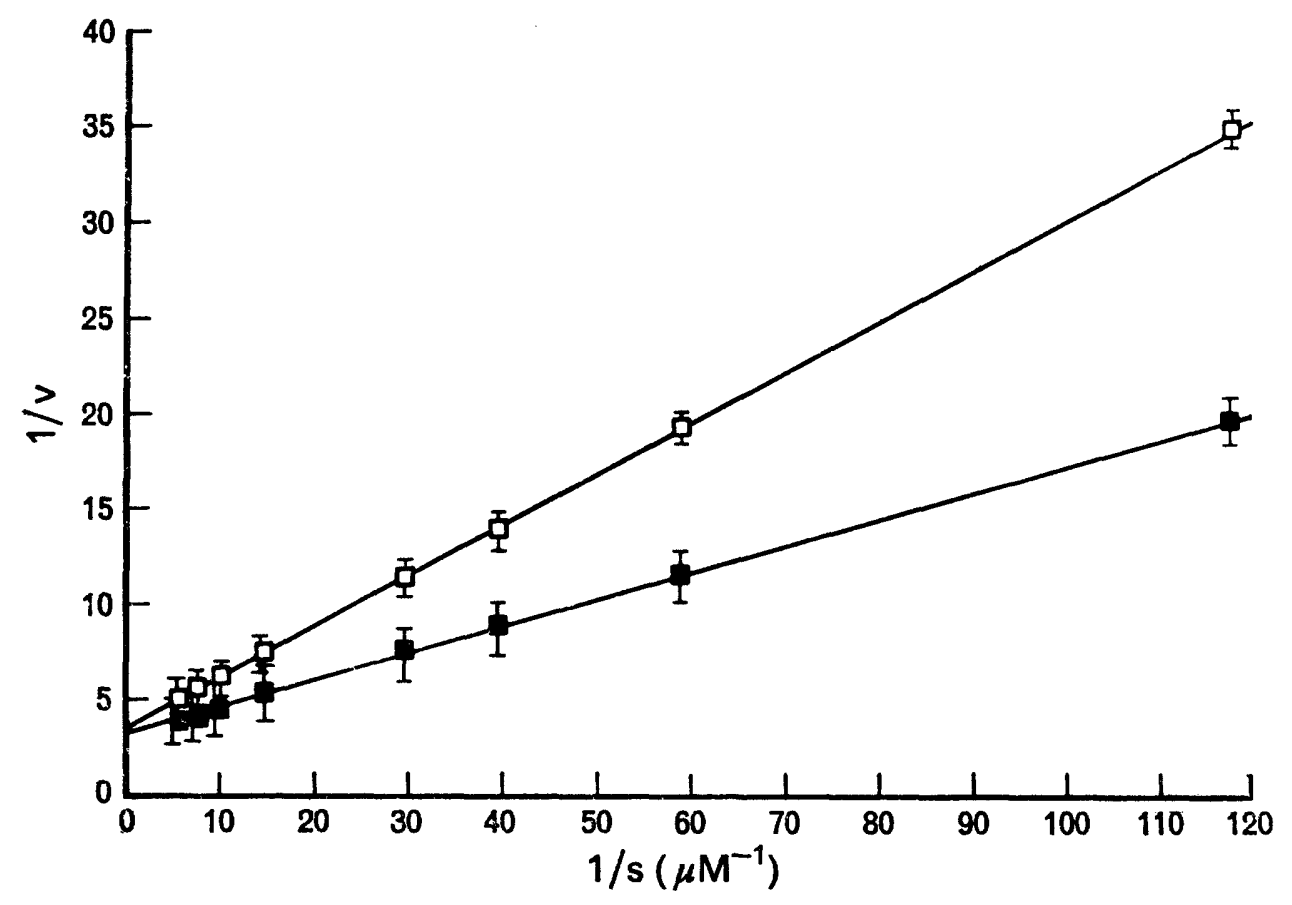

Fig. 3.-Plot of $1 / \mathrm{v}$ against $1 / \mathrm{s}$ (Lineweaver-Burk) for activated $\alpha$-toxin ( $\square$ ) and trypsin $(\square)$. $V_{\max }$ (extinction change in min.-1 at $247 \mathrm{~nm}$ ) is the reciprocal of the y-intercept and $\mathrm{K}_{\mathrm{m}}$ was calculated from an extrapolation of the two lines to the $x$-axis. $\mathbf{K}_{m}$ is independent of enzyme concentration. 
to that of the unknown were in fact methionine, leucine and isoleucine. The Rf values of 20 other amino acids tested were quite different when compared with that of the unknown. Filtration had no effect on resolution of DNPamino acids of activated toxin.

Comparative kinetics of TAME hydrolysis by activated toxin and trypsin. In this experiment, TAME and activated toxin, dissolved in $0.01 \mathrm{M}$ sodium

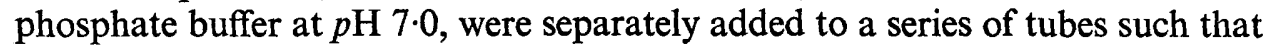
the final concentration of TAME ranged from 40-2000 $\mu \mathrm{g}$. The amount of toxin contained in each tube was constant at $37 \mathrm{HU}$ per $\mathrm{ml}$. In the trypsin experiment, the range of concentration of TAME was the same but that of trypsin was $20 \mu \mathrm{g}$ per tube. These solutions were incubated at $37^{\circ} \mathrm{C}$ in singlecompartment cuvettes in the spectrophotometer and readings at $247 \mathrm{~nm}$ were taken automatically at 3-s intervals over a period of $7 \mathrm{~min}$. A LineweaverBurk plot was constructed from the data obtained and is shown in fig. 3 . Plots of $1 / \mathrm{v}$ versus $1 / \mathrm{s}$ for toxin and trypsin are significantly different as shown by $95 \%$ confidence limits placed about the lines. From the graph it can be determined that $\mathrm{V}_{\max }$ for toxin is $0.26 \mathrm{~min}$. $^{-1}$ while that for trypsin is nearly identical at 0.27 . However, the value of $\mathrm{K}_{\mathrm{m}}$ for toxin as obtained by extrapolation is $0.040 \mu \mathrm{M}$ in contrast to a value of $0.072 \mu \mathrm{M}$ for trypsin. Although dryweight concentrations of toxin and trypsin in this experiment were not strictly comparable, advantage was taken of the fact that under specified conditions and with the same substrate, $K_{m}$ is independent of enzyme concentration.

\section{Discussion}

We feel that these observations contribute further to the theory that the $\alpha$-toxin of $S$. aureus is a zymogen. Conversion of the protoxin to the active form can be effected by activating enzymes derived from suitable erythrocyte membranes or by trypsin. The time of exposure of protoxin to CMC-trypsin complex is important, because activation is quickly followed by degradation of the toxin molecule. It is impossible to prevent some loss of toxin activity but this can be minimised to an acceptable level provided that the 30-s period of incubation followed by a 15-min. "cold" centrifugation is not exceeded.

It might be argued that $\alpha$-toxin in contact with CMC-trypsin complex removed the trypsin from the $\mathrm{CMC}$ and that the liberated trypsin is responsible for hydrolysis of TAME. There would appear to be no force to this argument, because statistical analysis of the data (fig. 3 ) showed that plots of $1 / v$ versus $1 / \mathrm{s}$ for trypsin and toxin are significantly different at the $1 \%$ level, indicating that the toxin has a greater affinity for TAME than trypsin. Apart from this, activated toxin and trypsin are similar in several respects. Both are produced as inactive precursors and will attack TAME. Furthermore, the N-terminus of bovine trypsin is isoleucine as shown by Rovery, Fabre and Desnuelle (1952, cited by Dixon and Webb, 1964). The N-terminus of activated $\alpha$-toxin is either leucine or isoleucine. Trypsin and erythrocyte-membrane proteases may activate $\alpha$-protoxin by removing a short peptide (with histidine as the $\mathrm{N}$-terminus) from the $\mathrm{N}$-terminal end of the molecule which exposes the active 
centre, in a manner analogous to that in which trypsinogen is activated. Six and Harshman (1973a and $b$ ) have recently shown that their purified $\alpha$-haemolysin contains two components that they have designated A and B. The Nterminus of both forms was alanine. Our findings are not in keeping with this observation although we note that the 5th amino acid along from the N-terminal alanine residue in their material is isoleucine. It is possible that differences in strains, in the composition of the media or in levels of other proteases may be responsible for this discrepancy.

Little or no protoxin was recovered after passage through a Swinney filter. By contrast, $65 \%$ of activated toxin was recovered after membrane filtration. It is difficult to explain why partial rather than full recovery of the toxin was obtained. It may be the result of incomplete activation of protoxin by trypsin, with $35 \%$ of the toxin being unfiltrable because it was not activated. In any case, the differential recovery of the two toxins must reflect a change in size, conformation or charge when the molecule is activated.

It has come to our attention that Freer, Arbuthnott and Billcliffe (1973) have been unable to associate proteolytic activity with their $\alpha$-toxin preparations derived from the Wood-46 strain. However, they failed to look for protease activity in their membrane suspensions. It is quite possible that activator was lost in the preparation of their ghosts or that under the conditions of their experiments the protease activator was inactive. In this connection it is well to take note of the work of Dodge, Mitchell and Hanahan (1963), who showed that the method of preparation greatly affected the quality of the ghosts.

Alpha toxin has also been reported to have surface activity. Weissmann, Sessa and Bernheimer (1966) and Freer, Arbuthnott and Bernheimer (1968) have observed that $\alpha$-toxin disrupted artificial lipid membranes. Buckelew and Colacicco (1971) have demonstrated that the toxin readily spreads as a film on aqueous media and that penetration of toxin into lipid monolayers is related to the structure of the lipid. Film penetration was greatest with cholesterol and least with ganglioside. Arbuthnott, Freer and Billcliffe (1973) have noted that lipids differed in their ability to induce polymerisation of $3 \mathrm{~S}$ toxin, diglyceride being the most effective and lysolecithin the least.

However, as pointed out by Camejo, Colacicco and Rapport (1968), most lipids and proteins display some degree of association when brought together. There is a difficulty in accepting the view that the surface activity of $\alpha$-toxin and its interaction with membrane lipids are responsible for haemolysis of sensitive erythrocytes and other biological properties attributed to the toxin. This is that it has not been possible to establish that the surface activity of the toxin can alone account for its biological specificity.

At present it is not entirely possible to reconcile the $\alpha$-toxin's surface activity with our view that the toxin is an enzyme that degrades membrane protein when activated by membrane protease. Perhaps the interaction of toxin with membrane lipids might serve to anchor it in a particular conformation that is susceptible to the action of the activating protease. 


\section{SUMMARY}

Alpha protoxin of Staphylococcus aureus "Wood 46" was activated by trypsin which had been coupled to carboxymethylcellulose, as indicated by the toxin's ability to hydrolyse tosyl-arginine methylester (TAME). A LineweaverBurk plot of the degradation of TAME by toxin and trypsin showed that toxin had a greater affinity for the substrate than had trypsin. N-terminal aminoacid analyses of activated toxin suggested that leucine or isoleucine is the $\mathrm{N}$-terminus, in contrast to protoxin, the $\mathrm{N}$-terminus of which is histidine.

This work was supported by the Medical Research Council of Canada.

\section{REFERENCES}

ArbuthnotT, J. P. 1970. Staphylococcal alpha toxin. In Microbial toxins, vol. 3, edited by S. J. Ajl and others, New York, p. 189.

ArbuthnotT, J. P., Freer, J. H. AND BillclifFe, B. 1973. Lipid-induced polymerization of staphylococcal alpha toxin. J. gen. Microbiol., 75, 309.

Bernheimer, A. W. AND SCHWARTZ, L. L. 1963. Isolation and composition of staphylococcal alpha toxin. J. gen. Microbiol., 30, 455.

BuCKelew, A. R. AND ColaCicco, G. 1971. Lipid monolayers. Interactions with staphylococcal alpha-toxin. Biochim. biophys. Acta, 233, 7.

CAMEJO, G., COlACICCO, G. AND RAPPORT, M. M. 1968. Lipid monolayers: interactions with the apoprotein of high density plasma lipoprotein. J. Lipid Res., 9, 562.

Campbell, D. H., Garvey, J. S., Cremer, N. E. AND Sussdorf, D. H. 1970. Methods in immunology, 2nd ed., New York, p. 216.

Dixon, M. AND WebB, E. C. 1964. Enzymes, 2nd ed., London, p. 528.

Dodge, J. T., Mirchell, C. AND Hanahan, D. J. 1963. The preparation and chemical characteristics of hemoglobin-free ghosts of human erythrocytes. Archs Biochem. Biophys., 100, 119.

FACKrell, H. B. 1973. Studies with gamma hemolysin of Staphylococcus aureus. Ph.D. Thesis, University of Manitoba.

FACKrell, H. B. AND Wiseman, G. M. 1975. Properties of the gamma hemolysin of Staphylococcus aureus "Smith 5R". J. gen. Microbiol., In press.

Fraenkel-ConRat, H., HaRris, J. I. AND LeVY, A. L. 1955. Recent developments in techniques for terminal and sequence studies in peptides and proteins. Meth. biochem. Anal., 2, 359.

Freer, J. H., Arbuthnott, J. P. AND Bernheimer, A. W. 1968. Interaction of staphylococcal alpha toxin with artificial and natural membranes. J. Bact., 95, 1153.

Freer, J. H., Arbuthnott, J. P. AND Billcliffe, B. 1973. Effects of staphylococcal alpha toxin on the structure of erythrocyte membranes: a biochemical and freeze-etching study. J. gen. Microbiol., 75, 321.

Gow, J. A. 1968. Purification and properties of staphylococcal alpha and beta hemolysins. M.Sc. Thesis, University of Western Ontario.

Gow, J. A. ANd Robinson, J. 1969. Properties of purified staphylococcal beta hemolysin. J. Bact., 97, 1026.

Hallander, H. O. 1963. Fractionation of staphylococcal toxins by gel filtration. Acta path. microbiol. scand., 59, 543.

HersKovits, T. T. 1967. In Methods in enzymology, vol. 11, New York, p. 771.

Hummel, B. C. W. 1959. A modified spectrophotometric determination of chymotrypsin, trypsin and thrombin. Can. J. Biochem. Physiol., 37, 1393.

PatakI, G. 1966. Techniques of thin-layer chromatography in amino acid and peptide chemistry, Berlin, p. 133. 
Robinson, J., Thatcher, F. S. ANd Montford, J. 1960. Studies with staphylococcal toxins. V. Possible identification of alpha hemolysin with a proteolytic enzyme. Can. J. Microbiol., 6, 183.

Six, H. R. ANd Harshman, S. 1973a. Purification and properties of two forms of staphylococcal alpha toxin. Biochemistry, 12, 2672.

Six, H. R. ANd Harshman, S. $1973 b$. Physical and chemical studies on staphylococcal alpha toxins A and B. Biochemistry, 12, 2677.

Weissmann, G., Sessa, G. AND Bernheimer, A. W. 1966. Staphylococcal alpha toxin: effects on artificial lipid spherules. Science, N.Y., 154, 772.

Wiseman, G. M. AND CAIRD, J. D. 1970. Mode of action of the alpha toxin of Staphylococcus aureus. Can. J. Microbiol., 16, 47.

Wiseman, G. M. AND CAIRD, J. D. 1972. Further observations on the mode of action of the alpha toxin of Staphylococcus aureus "Wood 46 ". Can.J. Microbiol., 18, 987.

Wittler, R. G. AND Pillemer, L. 1948. The immunochemistry of toxins and toxoids. V. The solubility of staphylococcal toxin in methanol-water mixtures under controlled conditions of $p \mathrm{H}$, ionic strength and temperature. J. biol. Chem., 174, 23. 